\title{
DOE/PC/92114-- T/0
}

GASOLINE FROM NATURAL GAS BY SULFUR PROCESSING

Quarterly Report No. 10 for the Period October-December 1995

By

Erek J. Erekson

R. Gopalakrishnan

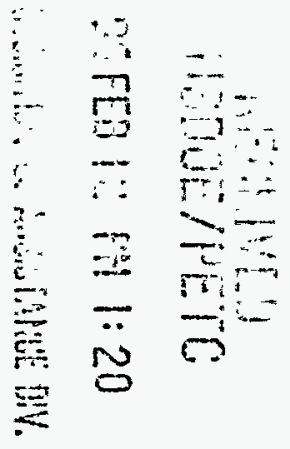

January 1996

Work Performed Under Contract No.: DE-AC22-93PC92114

For

U.S. Department of Energy

Pittsburgh Energy Technology Center

P.O. Box 10940

Pittsburgh, Pennsylvania 15236-0940

By

Institute of Gas Technology

1700 South Mount Prospect Road

Des Plaines, Illinois 60018-1804

TECHNICAL INFORMATION CENTER

OFFICE OF SCIENTIFIC AND TECHNICAL INFORMATION UNITED STATES DEPARTMENT OF ENERGY 


\section{DISCLAIMER}

This report was prepared as an account of work sponsored by an agency of the United States Government. Neither the United States Government nor any agency thereof, nor any of their employees, makes any warranty, express or implied, or assumes any legal liability or responsibility for the accuracy, completeness, or usefulness of any information, apparatus, product, or process disclosed, or represents that its use would not infringe privately owned rights. Reference herein to any specific commercial product, process, or service by trade name, trademark, manufacturer, or otherwise, does not necessarily constitute or imply its endorsement, recommendation, or favoring by the United States Government or any agency thereof. The views and opinions of authors expressed herein do not necessarily state or reflect those of the United States Government or any agency thereof.

Printed in the United States of America

Available from

National Technical Information Service

U.S. Department of Commerce

5285 Port Royal Road

Springfield, VA 22161

NTIS price codes

Printed copy:

Microfiche copy: 


\title{
GASOLINE FROM NATURAL GAS BY SULFUR PROCESSING
}

Quarterly Report No. 10 for the Period October-December 1995

\author{
By \\ Erek J. Erekson \\ R. Gopalakrishnan
}

January 1996

Work Performed Under Contract No.: DE-AC22-93PC92114

For

U.S. Department of Energy

Pittsburgh Energy Technology Center

P.O. Box 10940

Pittsburgh, Pennsylvania 15236-0940

\author{
By \\ Institute of Gas Technology \\ 1700 South Mount Prospect Road \\ Des Plaines, Illinois 60018-1804
}


. 


\section{EXECUTIVE SUMMARY}

This report presents the work performed at the Institute of Gas Technology (IGT) during the tenth program quarter from October 1 to December 31, 1995, under Department of Energy (DOE) Contract No. DE-AC22-93PC92114. This program has coordinated funding for Task 1 from IGT's Sustaining Membership Program (SMP), while DOE is funding Tasks 2 through 8. Progress in all tasks is reported here.

The overall objective of this research project is to develop a catalytic process to convert natural gas to liquid transportation fuels. The process consists of two steps that each use catalysts and sulfur-containing intermediates: 1) converting natural gas to $\mathrm{CS}_{2}$ and 2) converting $\mathrm{CS}_{2}$ to gasoline-range liquids. Experimental data will be generated to demonstrate the potential of catalysts and the overall process.

During this quarter, progress in the following areas has been made:

- Short duration activity test on catalyst IGT-MS-103 showed no deactivation over a 6 hour period;

- Preliminary data of $\mathrm{CS}_{2}$ reaction with $\mathrm{H}_{2}$ at $400-410{ }^{\circ} \mathrm{C}$ and at atmospheric pressure indicates that IGT-HS-103 is an active catalyst for hydrocarbon synthesis from $\mathrm{CS}_{2}$ and $\mathrm{H}_{2}$. 



\section{TABLE OF CONTENTS}

\section{Page}

INTRODUCTION 1

RESULTS AND DISCUSSION

Task 1. Catalyst Preparation (SMP Funded) 2

Task 2. Experimental Studies of the $\mathrm{H}_{2} \mathrm{~S}$ Decomposition Reaction 2

Task 3. Carbon Deposition Studies 2

Task 4. Experimental Studies of the Methane/Hydrogen Sulfide Reaction 3

Task 5. Experimental Studies of $\mathrm{CS}_{2}$ to Liquid Hydrocarbons 3

Task 6. Proof-of-Concept Testing 5

Task 7. Environmental Reporting 5

Task 8. Project Management and Technology Transfer 5

CONCLUSIONS 



\section{INTRODUCTION}

Natural gas is an abundant resource in various parts of the world. The major component of natural gas is methane, often comprising over $90 \%$ of the hydrocarbon fraction of the gas. The expanded use of natural gas as fuel is often hampered because of difficulties in storing and handling a gaseous fuel. This is especially true for natural gas in remote areas, such as the North Slope of Alaska. The successful implementation of a natural gas-to-gasoline process would decrease dependence on imported oil for transportation fuels. These factors make it very desirable to convert natural gas into valuable liquids.

There are commercial processes for converting natural gas to gasoline-range liquids. These processes, such as the Fischer-Tropsch synthesis and Mobil's MTG (Methanol To Gasoline), start with the steam reforming of methane. Steam reforming of methane requires the removal of sulfur compounds present in natural gas down to less than $0.1 \mathrm{ppm}$. This additional gas cleanup step, with its additional cost, is necessary because the catalysts are quickly poisoned by sulfur compounds.

In this program, IGT is investigating a two-step process that uses $\mathrm{H}_{2} \mathrm{~S}$ as a reactant to convert natural gas to gasoline-range liquids. In the first step of the process, methane is converted to $\mathrm{CS}_{2}$ and hydrogen:

$$
2 \mathrm{H}_{2} \mathrm{~S}+\mathrm{CH}_{4} \rightarrow \mathrm{CS}_{2}+4 \mathrm{H}_{2}
$$

In the second step, $\mathrm{CS}_{2}$ is hydrogenated to gasoline-range hydrocarbon liquids:

$$
\mathrm{CS}_{2}+3 \mathrm{H}_{2} \rightarrow-\left[\mathrm{CH}_{2}\right]-2 \mathrm{H}_{2} \mathrm{~S}(2)
$$

For the proposed process, a sulfur-removal step down to $0.1 \mathrm{ppm}$ with associated guard beds is not necessary. Sulfur, usually considered a poison, is used as a reactant. This method of methane conversion uses $\mathrm{H}_{2} \mathrm{~S}$ to convert methane to $\mathrm{CS}_{2}$. Then $\mathrm{CS}_{2}$ and hydrogen can be catalytically converted to gasoline-range hydrocarbons. All the $\mathrm{H}_{2} \mathrm{~S}$ generated during the $\mathrm{CS}_{2}$-togasoline reaction is recycled. An additional advantage of the proposed process is that the hydrogen required for the process is produced in Step 1 without using a steam reformer. 
The proposed process has the potential for improving the overall economics of natural gas conversion, which could result in much more natural gas being used to make liquid fuels, thus decreasing the U.S. dependence on foreign sources of oil.

\section{RESULTS AND DISCUSSION}

\section{Task 1. Catalyst Preparation (SMP Funded)}

The purpose of this task is to prepare the catalysts according to both conventional and IGT proprietary methods for evaluation in the reactions studied in Tasks 2 through 5.

A batch of IGT-HS-103, metal ion exchanged zeolite based hydrogenation catalysts, was prepared by ion exchange method and characterized for metal loading (56\%) and BET surface area $\left(347 \mathrm{~m}^{2} / \mathrm{g}\right)$.

\section{Task 2. Experimental Studies of the $\mathrm{H}_{2} \underline{\mathrm{S}}$ Decomposition Reaction}

The purpose of this task is to evaluate catalysts for the following reaction:

$$
2 \mathrm{H}_{2} \mathrm{~S} \rightarrow \mathrm{S}_{2}+2 \mathrm{H}_{2}
$$

In this task, we designed a group of tests for evaluating IGT catalysts. The reason for studying this reaction is to produce a group of catalysts that make gaseous sulfur. Gaseous sulfur is known to react with methane to form $\mathrm{CS}_{2}$, the desired product of Step 1 .

This task was inactive this quarter.

\section{Task 3. Carbon Deposition Studies}

As we develop a catalyst for the conversion of $\mathrm{CH}_{4}+\mathrm{H}_{2} \mathrm{~S}$, we want a catalyst that does not become deactivated by carbon deposition. In the temperature range that we will be testing, carbon formation is thermodynamically possible. We designed a group of tests to see if some carbon deposition occurred, whether the catalyst can be regenerated, and whether $\mathrm{CS}_{2}$ would be formed from the carbon on the catalyst surface.

This task was inactive this quarter. 


\section{Task 4. Experimental Studies of the Methane/Hydrogen Sulfide Reaction}

The objective of this task is to develop a group of catalysts for the direct conversion of methane and hydrogen sulfide to carbon disulfide. This task is divided into two parts. During the first part, 10 catalysts will be prepared and evaluated. A group of the best catalysts will be identified. The optimum operating conditions will also be determined. In the second part of this task, the most promising catalysts will be tested under the best operating conditions for sustained periods of time.

Catalyst testing was inactive this quarter.

With respect to the commercialization of the technology developed in this project, we have sent out brief summaries to managers at petroleum companies and designers of hydrogen plants. The summaries show how the catalysts developed for this task might be used in a refinery for the production of hydrogen and the conversion of hydrogen sulfide. The first step of the HSM process technology has advantages over conventional Claus and Tail Gas Cleanup technologies. A brief comparison of HSM and Claus follows.

\begin{tabular}{ll}
\hline \multicolumn{1}{c}{$\mathrm{HSM}$} & \multicolumn{1}{c}{ Claus } \\
\hline Converts $\mathrm{H}_{2} \mathrm{~S}$ to useful products $\left(\mathrm{H}_{2}, \mathrm{CS}_{2}\right)$ & Converts $\mathrm{H}_{2} \mathrm{~S}$ to useful product (S) \\
Produces hydrogen for use in refinery & Hydrogen in $\mathrm{H}_{2} \mathrm{~S}$ becomes water vapor \\
Sulfur product $\left(\mathrm{CS}_{2}\right)$ can be burned for $\mathrm{H}_{2} \mathrm{SO}_{4}$ & Sulfur is burned for $\mathrm{H}_{2} \mathrm{SO}_{4}$ \\
No waste is vented to the atmosphere & Water vapor and other gases are vented \\
No tail gas clean-up is needed & Requires tail gas clean-up unit \\
\hline
\end{tabular}

We will be following up with our contacts regarding their interest in the HSM technology for refinery applications.

\section{Task 5. Experimental Studies of $\mathrm{CS}_{2}$ to Liquid Hydrocarbons}

During this quarter efforts have focused on converting $\mathrm{CS}_{2}$ to hydrocarbons using $\mathrm{H}_{2}$ on IGT-HS-103 catalyst. $20 \mathrm{cc}$ of the catalyst was loaded in a quartz reactor. The reaction was carried out by feeding $\mathrm{CS}_{2}$ and $\mathrm{H}_{2}$ at atmospheric pressure and at different temperatures and flow rates. The results are given in Table 1. During this study the runs were often interrupted due to 
unsteady $\mathrm{CS}_{2}$ liquid flows. The liquid has a boiling point of $46^{\circ} \mathrm{C}$, and it vaporizes easily in the piston area of the pump creating a gas bubble. The flow stops when gas bubbles move into the check valve. Therefore, the results of Table 1 are preliminary and need to be repeated.

Table 1. Hydrogenation of $\mathrm{CS}_{2}$ on IGT-HS-103

Catalyst volume $=20 \mathrm{cc} ;$ Pressure $=1 \mathrm{~atm}$.

\begin{tabular}{ccccc}
\hline $\begin{array}{c}\text { Temperature } \\
\left({ }^{\circ} \mathrm{C}\right)\end{array}$ & $\begin{array}{c}\mathrm{CS}_{2} \text { flow } \\
(\mathrm{LHSV})\end{array}$ & $\begin{array}{c}\mathrm{H}_{2} \text { flow } \\
(\mathrm{GHSV})\end{array}$ & $\begin{array}{c}\mathrm{CS}_{2} / \mathrm{H}_{2} \\
\text { (mole ratio) }\end{array}$ & $\begin{array}{c}\mathrm{CS}_{2} \text { conversion } \\
(\%)\end{array}$ \\
\hline 407 & 0.664 & 399 & 0.69 & 16 \\
400 & 0.521 & 399 & 0.54 & 12 \\
417 & 0.403 & 399 & 0.42 & 50 \\
\hline
\end{tabular}

Under the experimental conditions $\left(\mathrm{CS}_{2} / \mathrm{H}_{2}=0.42\right.$ to 0.69$)$, no condensation of $\mathrm{CS}_{2}$ in the products was found. The vapor pressure of $\mathrm{CS}_{2}$, for example, at $25^{\circ} \mathrm{C}$ is about $0.45 \mathrm{~atm}$. The gas products were analyzed in $\mathrm{GC}$ and the $\mathrm{CS}_{2}$ conversions were calculated from the feed and exit concentrations. Hydrocarbons were observed by GC (the GC could detect only up to C4) but they were not quantified. Further experiments will focus on quantifying individual hydrocarbons and also changing the reaction parameters, feed concentration, temperature, etc.

The results can be compared with previous Mobil work (US Patent 1985, US 4,543,434). The results of Mobil study are given in Table 2.

Table 2. Hydrogenation of $\mathrm{CS}_{2}$ over a mixture of $50 \% \mathrm{HZSM}-5 / \mathrm{Al}_{2} \mathrm{O}_{3}$ and $50 \% \mathrm{Co} / \mathrm{SiO}_{2}$ Catalyst volume $=$ unknown; Pressure $=250$ psig.

\begin{tabular}{ccccc}
\hline $\begin{array}{c}\text { Temperature } \\
\left({ }^{\circ} \mathrm{C}\right)\end{array}$ & $\begin{array}{c}\mathrm{CS}_{2} \text { flow } \\
(\mathrm{LHSV})\end{array}$ & $\begin{array}{c}\mathrm{H}_{2} \text { flow } \\
(\mathrm{GHSV})\end{array}$ & $\begin{array}{c}\mathrm{CS}_{2} / \mathrm{H}_{2} \\
(\text { mole ratio })\end{array}$ & $\begin{array}{c}\mathrm{CS}_{2} \text { conversion } \\
(\%)\end{array}$ \\
\hline 482 & 1 & 400 & 0.93 & 40.3 \\
\hline
\end{tabular}

In order to obtain a constant flow of $\mathrm{CS}_{2}$ liquid, we used a syringe pump, but the o-rings in the piston expanded when it came into contact with $\mathrm{CS}_{2}$. Eventually the syringe stopped 
operation. To solve the $\mathrm{CS}_{2}$ delivery problem and to obtain constant flow, we changed the delivery configuration to a pressurized container with a micrometer valve to control the flow. Nitrogen is used to pressurize the container to 7 psig. $\mathrm{CS}_{2}$ liquid flows out of the bottom of the container. Test runs were carried out to repeat the conditions of earlier Mobil work where $\mathrm{CS}_{2} / \mathrm{H}_{2}=1$. However, at this higher $\mathrm{CS}_{2} / \mathrm{H}_{2}$ ratio $\mathrm{CS}_{2}$ was condensing in the quartz bulb after the reactor. Since the products were sampled by a gas syringe, it was difficult to quantify $\mathrm{CS}_{2}$ concentration. To alleviate this, we have installed a heating mantle to prevent the liquid condensation in the quartz bulb after the reactor. Also, we have installed a GC-sampling point close to the quartz bulb with additional heating along the gas line up to the sampling point to keep the products in vapor phase. Test runs will be conducted soon and will be reported in the next monthly report.

\section{Task 6. Proof-of-Concept Testing}

This task was inactive this period.

Task 7. Environmental Reporting

This task was inactive this period.

Task 8. Project Management and Technology Transfer

This task was inactive this period.

\section{CONCLUSIONS}

- There is interest within the oil companies we contacted for a process that converts natural gas to liquid hydrocarbons. In addition there is also interest in a process that produces hydrogen for a refinery, while at the same time it removes hydrogen sulfide.

- Preliminary data of $\mathrm{CS}_{2}$ reaction with $\mathrm{H}_{2}$ at $400-410^{\circ} \mathrm{C}$ and at atmospheric pressure indicates that IGT-HS-103 is an active catalyst for hydrocarbon synthesis from $\mathrm{CS}_{2}$ and $\mathrm{H}_{2}$. 
